\title{
Inter-region Economic Analysis to Improve Economic Development Maritime In North Maluku Province
}

\author{
Musdar Muhammd, Devanto, Wildan Syafitri \\ Master Program of Economics Faculty of Economics and Business \\ Brawijaya University \\ Email: musdarepa@ymail.com
}

Received: July 12, 2016; Accepted: October 21, 2016; Published: March 2, 2017

Permalink/DOI: http://dx.doi.org/10.17977/um002v9i12017p001

\begin{abstract}
The main purpose of this research to analysis sector and sub-sector development of chartered investment counsel maritime between regions which is bases sector in sub-province and opportunity of job activity at subsector fishery of sub-province in North Maluku with observation PDRB subprovince/town during five years (2009-2013). Then, analyses development policy strategy of chartered investment counsel maritime North Maluku. By using technique analyses LQ, multiplier effect, and AHP. The result of analysis shows sub-province Halmahera South and second archipelago Sula of the sub-province that there is sector and sub-sector bases which at most when in comparing to sector and sub-sector bases there is sub-province/town province North Maluku, multiplier effect opportunity of job activity at subsector fishery happened in the year 2010 that there is in sub-province/city West Halmahera, South-east Halmahera, East Halmahera North Halmahera, and city of Tidore archipelago's. In the year of 2013, multiplier effect subsector fishery catches there is at sub-province West Halmahera, South Halmahera, and the city of Tidore archipelagoes. Development policy strategy of chartered investment counsel maritime human resource, public service, natural resources with fishery \& oceanic requirement in making a preference for development of chartered investment counsel maritime of North Maluku.
\end{abstract}

Keywords: Economic Between Regions, Pre-Eminent Sector, Development Economic Maritim

JEL Classification: O18, R11

\section{INTRODUCTION}

Indonesia is an archipelago, which is often called the world's largest maritime country. Indonesia consists of 17,508 islands scattered around the Equator, Total area of the archipelago Indonesia reaches approximately 8 million square kilometers, the territorial waters or the sea is about two-thirds of the total territory of Indonesia and the remaining third of the land, the territory of a maritime country covering land and marine areas (Adisasmita, 2013).

Law No. 22 of 1999 on Regional Government which was amended by Act No. 32 of 2004, One of them is that local governments have the authority, as local governments and local communities who can best identify potential areas as well as the development needs of the region, the development of the region in 
improving primary sector, secondary and tertiary. Economic growth is the increase in output per capita in the long term.

North Maluku province is an island province with has 805 large and small islands, and up to this time the number of the new inhabited island 82 pieces. which has many straits, bays, and islands. The island province has an area of $145,801.1 \mathrm{~km} 2$ with about 69 and 1 percent of the ocean. The long coastline of North Maluku province is $6644 \mathrm{~km}$, to the vast amount of protected areas in the province of North Maluku 15731.36 Ha. In the Medium Term Development Plan of North Maluku provincial government five years (2014-2019) to make the maritime sector as a development priority in North Maluku that potential it can contribute substantially to increased local revenues (district/city) and public welfare.

North Maluku province is dominated by the coastal region consists of islands large and small, coastal resources contained in the district/city of the province of North Maluku very important role in supporting regional economic development to increase foreign exchange earnings, employment, and incomes of the population. The coastal resources has a comparative advantage because it is available in a number of large, diverse, and can be utilized with exploitation costs are relatively low so as to create a competitive bidding capacity (Kaczynski \& Looney, 2000; Riyadi \& Smith, 2005).

According to Adisasmita (2013), maritime defined as activities on the coast to the sea. Furthermore, The development of maritime development is related to the interaction of human resources, natural resources, infrastructure, maritime development in the islands and the linkages between islands which connect the water or the sea, where the emphasis is on the plains of the island, the sea as a support Adisasmita (2013). To do with the development of these sectors and sub-sectors of the economy are seeded based on the distinctiveness or regional characteristics and their relation to each district/city and increase employment opportunities in supporting economic development in the maritime province of North Maluku.

\section{LITERATURE REVIEW}

\section{Definition of Maritime Economics and Economic Development Maritime}

According to Adisasmita (2013), there are several terms that are similar but different emphasis, namely Maritime Economy, Economic Islands, Maritime Economy, and Economy Archipelago. Maritime Economy in collaboration with the maritime transportation system, the role, and function of the port maritime and island-based development, maritime regional system, the development of coastal areas, fisheries and marine resource potential, spatial planning of coastal areas, as well as the objectives and elements of maritime development (Jiang \& Liu, 2014).

Meanwhile, according to Palgrave (2006) is a maritime economy or they also call the Maritime Economics and Logistics is the integrated study of marine transportation, seaport, as well as global supply chain management. In another definition explains, maritime law is a body that sets rules for trade that occurred in the seas and oceans (Manik \& Sari, 2014).

Kamaluddin \& Laode (2002) defines the maritime economy is part of economics that studies the structure of the economy is moving in the transportation and sea transportation, ports (including the shipbuilding industry), 
fisheries, marine tourism, energy and mining prisons beach, accompanied by human resources in the maritime sector. Furthermore, Kamaluddin \& Laode (2002) add, Belt maritime economy is a design-oriented economic development with an emphasis on building maritime network of centers linking economic growth and trade between the small islands and coastal cities.

Maritime economic development is the study of learning about the increase of production capacity to undertake economic development in the area of maritime waterside beach that interacts with water/sea, as the media or the construction purpose's, as the perpetration of development. The main orientation is more in the direction of development at the water/sea than on land towards (Adisasmita, 2013; Budianto et al., 2013).

Development of maritime very broad aspects, namely: involving the participation and empowerment of human resources (HR), capital resources (working capital and investment capital), resources, facilities and infrastructure (docks sea and cold storage), natural resources covering resources coastal and marine resources technology (engine motor boats, appropriate technology), institutional resources (fishing cooperatives and others), and the resources of coastal communities at large.

\section{The role of the Maritime Economic Development}

Interaction maritime economic development is very broad, covering various aspects and sectors, which puts the role of the maritime economic development in a very important position in the development of national and regional development (Dahuri \& Nugroho, 2012; Adisasmita, 2013) in terms of: (1) As a container or arena (media) activities arrest fish and other marine products. (2) Serving the marine transport activities using ships, motor boats or sailboats motor to transport goods and people from point of origin to point of destination, from the production area to marketing area lying scattered. (3) Serving trade activities between the islands, serve the delivery of agricultural commodities in the broad sense (food crops, plantations, fisheries, animal husbandry, and forestry) and manufactured goods from the port area to the port production in the area of consumption. (4) The construction of the maritime sector is very broad, the development activities in the sector maritime include various productive activities that produce outputs of goods and services.

\section{Maritime Economic Indicators}

According to Gusman (2015), there are three indicators in developing the maritime economy, namely; (1) the sea as a source of life and livelihood livelihoods are managed optimally and sustainably (2) Economic or trade, and (3) the Navy is able to protect and defend national sovereignty. Furthermore, Aminuddin (2015) convey, consisting of three indicators in developing the maritime economy, namely; production of fishery products, development of fishing ports, and increase the area of marine conservation.

\section{Theory of Economic Base}

Activity in the regional economy is classified into two sectors of activity namely, the activity of the base and non-base. Base activities are activities that do export-oriented activities (goods and services) out of bounds the economy is 
concerned. Eraser changes that occur in the base sector will lead to a double effect in the regional economy. The Economic base theory states that the main determinants of economic growth of a region is directly related to the demand for goods and services from outside the area. The growth of industries that utilize local resources, including labor force and raw materials for export, will generate regional wealth and employment creation (Arsyad, 1999). According to Sjafrizal (2008), the basic principles of the Comparative Advantage Model is as follows: when the mobility of resources (factors) between regions is not smooth, then the public an area will be better off if the focus (specialize) on production activities that the region can produce it with a relatively cheaper cost (more efficient) compared to other regions.

\section{METHOD}

The research approach is descriptive research with survey method (Arikunto, 2000). The object of this study focused on eight counties and two cities of North Maluku province, namely; West Halmahera, Central, South Halmahera, North Halmahera, East Halmahera, Sula Islands, Morotai, Ternate, Tidore Islands namely: By analyzing the sectors and sub-sectors leading economic relating to the development of the maritime economy, employment opportunities and strategies policy in improving the maritime economy in the district/city of North Maluku province. The data used in this study are primary data (obtained directly from the respondent, through the technique of in-depth interviews, questionnaires with the stakeholder and related parties as many as twelve (12) namely: the provincial government of North Maluku, DPRD of North Maluku province, faculty, and community leaders fisherman/living in the coast area and secondary data (the data is data Gross Regional Domestic Product (PDRB) district/city and the province of North Maluku in the GDP from 2009 to 2013 according to the business field and constant prices, labor data).

The analysis used the method of Location Quotient (LQ) to determine the sectors and subsectors are seeded in the district/city, the Securities Multiplier Effect based on the chance of labor in sub-sectors of fisheries, and Analytical Hierarchy Process (AHP) using the program Expert Choice 11, strategy development policy making to develop the maritime economy.

\section{RESULT AND DISCUSSION}

\section{LQ Analysis Results Agricultural Sector Regency/City of North Maluku province}

Based on the calculation Location Quotient (LQ) in Table 1 for the year 2009 until the year 2013, the Identified there are eight (8) districts/cities namely, district of South Halmahera, North Halmahera, West Halmahera, East Halmahera, Sula Islands, Island Morotai and Tidore maritime. The agricultural sector is a sector basis in LQ value greater than one (LQ> 1).

Table 1. Agricultural Sector LQ District/City of North Maluku Province

\begin{tabular}{ccccccc}
\hline \multirow{2}{*}{ Regency/City } & \multicolumn{5}{c}{ Agriculture sector } & \multirow{2}{*}{ Information } \\
\cline { 2 - 6 } & \multicolumn{5}{c}{ Year $\mathbf{2 0 0 9 - 2 0 1 3}$} & \\
\cline { 2 - 6 } & $\mathbf{2 0 0 9}$ & $\mathbf{2 0 1 0}$ & $\mathbf{2 0 1 1}$ & $\mathbf{2 0 1 2}$ & $\mathbf{2 0 1 3}$ & \\
\hline South Halmahera & 1,05 & 1,03 & 1,04 & 1,03 & 1,02 & Base \\
\hline
\end{tabular}




\begin{tabular}{|c|c|c|c|c|c|c|}
\hline \multirow{3}{*}{ Regency/City } & \multicolumn{5}{|c|}{ Agriculture sector } & \multirow{3}{*}{ Information } \\
\hline & \multicolumn{5}{|c|}{ Year 2009-2013 } & \\
\hline & 2009 & 2010 & 2011 & 2012 & 2013 & \\
\hline North Halmahera & 1,21 & 1,26 & 1,27 & 1,28 & 1,29 & Base \\
\hline West Halmahera & 1,13 & 1,17 & 1,18 & 1,22 & 1,22 & Base \\
\hline East Halmahera & 1,49 & 1,47 & 1,45 & 1,45 & 1,43 & Base \\
\hline Central Halmahera & 1,31 & 1,25 & 1,22 & 1,21 & 1,19 & Base \\
\hline Sula Islands & 1,03 & 1,04 & 1,07 & 1,09 & 1,11 & Base \\
\hline Morotai Island & 1,16 & 1,17 & 1,18 & 1,18 & 1,20 & Base \\
\hline Tidore & 1,36 & 1,37 & 1,37 & 1,38 & 1,40 & Base \\
\hline Ternate & 0,34 & 0,31 & 0,30 & 0,29 & 0,28 & Nonbase \\
\hline
\end{tabular}

Source: Data Processed, 2016

Analysis LQ Fisheries Sector Sub District/City of North Maluku Province.

Table 2. LQ Fisheries Sector Sub District/City of North Maluku Province

\begin{tabular}{lcccccc}
\hline \multirow{1}{*}{ Regency/City } & \multicolumn{5}{c}{ Fisheries subsector } & \multirow{2}{*}{ Information } \\
\cline { 2 - 6 } & \multicolumn{5}{c}{ Year 2009-2013 } & \\
\cline { 2 - 6 } & $\mathbf{2 0 0 9}$ & $\mathbf{2 0 1 0}$ & $\mathbf{2 0 1 1}$ & $\mathbf{2 0 1 2}$ & $\mathbf{2 0 1 3}$ & \\
\hline South Halmahera & 1,16 & 1,15 & 1,16 & 1,15 & 1,15 & Base \\
\hline North Halmahera & 0,93 & 0,89 & 0,91 & 0,94 & 0,93 & Nonbase \\
\hline West Halmahera & 0,76 & 0,74 & 0,75 & 0,74 & 0,74 & Nonbase \\
\hline East Halmahera & 1,81 & 1,79 & 1,77 & 1,75 & 1,71 & Base \\
\hline Central Halmahera & 1,23 & 1,18 & 1,16 & 1,16 & 1,16 & Base \\
\hline Sula Islands & 0,99 & 1,15 & 1,19 & 1,24 & 1,26 & Base \\
\hline Morotai Island & 1,31 & 1,30 & 1,30 & 1,29 & 1,33 & Base \\
\hline Tidore & 1,44 & 0,64 & 1,42 & 1,40 & 1,41 & Base \\
\hline Ternate & 0,43 & 0,39 & 0,37 & 0,36 & 0,36 & Nonbase \\
\hline
\end{tabular}

Source: Data Processed, 2016

Regency of South Halmahera, East Halmahera, Central Halmahera, Sula Islands and Tidore islands, fisheries subsector has an LQ value greater than one (LQ> 1) so that the fisheries subsector is the subsector that the base of the sixth district/city and have the ability to export fishery subsector to another region. Based on the magnitude of the value contained in the fisheries subsector LQ East Halmahera district with LQ value of 1,81pada in 2009 and in 2013 amounted to 1.71. such as described in Table 2.

District/city has a fisheries subsector that basis, its just because of people in the district/city is a large part of the fishing community and the number of regions in the districts/cities are as big an ocean.

\section{Manufacturing Sector Analysis Results District/City of North Maluku Province}

The manufacturing sector, based on the Location Quotient (LQ) districts/ cities, the manufacturing sector in 2009 until 2013. South Halmahera District, North Halmahera, Sula Islands and the island of Morotai LQ has a value greater than one (LQ > 1), four districts/cities that the manufacturing sector is a sector basis and has the ability to export to other regions. 
Table 3. LQ Manufacturing Sector Regency/City of North Maluku Province

\begin{tabular}{lcccccc}
\hline \multirow{2}{*}{ Regency/City } & \multicolumn{5}{c}{ Manufacturing Sector } & \multirow{2}{*}{ Information } \\
\cline { 2 - 6 } & \multicolumn{5}{c}{ Year 2009-2013 } & \\
\cline { 2 - 6 } & $\mathbf{2 0 0 9}$ & $\mathbf{2 0 1 0}$ & $\mathbf{2 0 1 1}$ & $\mathbf{2 0 1 2}$ & $\mathbf{2 0 1 3}$ & \\
\hline South Halmahera & 1,53 & 1,57 & 1,58 & 1,57 & 1,56 & Base \\
\hline North Halmahera & 1,45 & 1,43 & 1,43 & 1,45 & 1,46 & Base \\
\hline West Halmahera & 1,39 & 0,53 & 1,41 & 1,42 & 1,43 & Base \\
\hline East Halmahera & 0,45 & 0,50 & 0,53 & 0,55 & 0,58 & Nonbase \\
\hline Central Halmahera & 0,41 & 0,40 & 0,40 & 0,55 & 0,41 & Nonbase \\
\hline Sula Islands & 1,55 & 1,54 & 1,48 & 1,45 & 1,43 & Base \\
\hline Morotai Island & 1,60 & 1,62 & 1,63 & 1,65 & 1,66 & Base \\
\hline Tidore & 0,39 & 0,38 & 0,39 & 0,40 & 0,41 & Nonbase \\
\hline Ternate & 0,43 & 0,39 & 0,38 & 0,38 & 0,38 & Nonbasis \\
\hline Source: Date
\end{tabular}

Source: Data Processed, 2016

\section{Sector Analysis Results of Trade, Hotels \& Restaurants Regency/City of North Maluku Province.}

There are only four districts/cities has a value greater LQ (LQ>1) is a sector basis, the fourth district/city consists of; South Halmahera regency, West Halmahera, Sula Islands and the city of Ternate, trade, hotels \& restaurants is a sector basis. The fourth provision of infrastructure is very good when compared with the district/city to the other in the province. Ternate is a city with a very crowded trade and provision of hotel and restaurant very much and there is completeness infrastructure if, in comparison with the district/city to the other in North Maluku.

Table 4. LQ Trade Sector, Hotel \& Restaurant Regency/City of North MalukuP.

\begin{tabular}{lcccccc}
\hline \multirow{1}{*}{ Regency/City } & \multicolumn{5}{c}{ The Trade, Hotel \& Restaurant } & \multirow{2}{*}{ Information } \\
\cline { 2 - 6 } & \multicolumn{5}{c}{ Year 2009-2013 } & \\
\cline { 2 - 6 } & $\mathbf{2 0 0 9}$ & $\mathbf{2 0 1 0}$ & $\mathbf{2 0 1 1}$ & $\mathbf{2 0 1 2}$ & $\mathbf{2 0 1 3}$ & \\
\hline South Halmahera & 1,03 & 1,06 & 1,07 & 1,09 & 1,10 & Base \\
\hline North Halmahera & 0,80 & 0,78 & 0,77 & 0,76 & 0,78 & Nonbase \\
\hline West Halmahera & 1,11 & 1,12 & 1,09 & 1,08 & 1,08 & Base \\
\hline East Halmahera & 0,76 & 0,77 & 0,80 & 0,83 & 0,85 & Nonbase \\
\hline Central Halmahera & 0,80 & 0,83 & 0,86 & 0,83 & 0,89 & Nonbase \\
\hline Sula Islands & 1,07 & 1,05 & 1,04 & 1,03 & 1,02 & Base \\
\hline Morotai Island & 0,88 & 0,88 & 0,88 & 0,91 & 0,89 & Nonbase \\
\hline Tidore & 1,03 & 1,02 & 1,01 & 1,00 & 0,98 & Nonbase \\
\hline Ternate & 1,27 & 1,15 & 1,15 & 1,14 & 1,12 & Base \\
\hline Soure
\end{tabular}

Source: Data Processed, 2016

\section{Result Analysis of Sea Transport Sector Sub District/City of North Maluku Province}

North Maluku sea transport sub-sector community activities have an important role to connect between regions. The results of the analysis LQ sea transport sub-sector in 2009 until the year 2013 there were five districts/cities have LQ value greater than one (LQ>1) which shows the sea transport sub-sector as a sector basis. Namely South Halmahera regency, West Halmahera, Central Halmahera, Sula Islands and Tidore This is because the sea transport sector which used public district/city to conduct economic activity. There exist three 
districts/cities have more than one value LQ, sea transport subsector is non-base sub-sector. As shown in Table 5.

Table 5. LQ Marine Transport Sector Sub District / City of North Maluku Province

\begin{tabular}{|c|c|c|c|c|c|c|}
\hline \multirow[t]{3}{*}{ Regency/City } & \multicolumn{5}{|c|}{ Sub Sea Transport Sector } & \multirow[t]{3}{*}{ Information } \\
\hline & \multicolumn{5}{|c|}{ Year 2009-2013 } & \\
\hline & 2009 & 2010 & 2011 & 2012 & 2013 & \\
\hline South Halmahera & 1,28 & 1,30 & 1,27 & 1,26 & 1,26 & Base \\
\hline North Halmahera & 0,82 & 0,75 & 0,75 & 0,77 & 0,76 & Nonbase \\
\hline West Halmahera & 1,11 & 1,09 & 1,06 & 1,04 & 1,05 & Base \\
\hline East Halmahera & 1,07 & 1,07 & 1,04 & 1,03 & 1,04 & Base \\
\hline Central Halmahera & 1,27 & 1,30 & 1,28 & 1,03 & 1,22 & Base \\
\hline Sula Islands & 1,10 & 1,07 & 1,22 & 1,27 & 1,30 & Base \\
\hline Morotai Island & 0,89 & 0,90 & 0,90 & 0,91 & 0,90 & Nonbase \\
\hline Tidore & 1,02 & 1,06 & 1,04 & 1,04 & 1,06 & Base \\
\hline Ternate & 0,72 & 0,67 & 0,67 & 0,67 & 0,66 & Nonbase \\
\hline
\end{tabular}

Source: Data Processed, 2016

According to Adisasmita (2013), increased activity in an area basis will increase the flow of revenue to the region concerned, which in turn increases demand for goods and services in the region and eventually will lead to the increase in the volume of non-base activities. Instead of less base activity will decrease the revenue of flowing into the area, which will cause decrease non base demand for products and activities. The results of the study, Sudarya et al., (2013). Economic development of the region's development guidelines coastal districts in Garut district concluded that the priority of economic development is mainly directed to agriculture, manufacturing, trade, hotel and restaurant sector, gas, electricity and drinking water. In which areas have the opportunity and authority to make policies that correspond to the potential of the area in order to accelerate the economic development of the region to improve the welfare of society (Bernacki, 2014).

\section{Results Multiplier Effect Analysis Based Employment Opportunities At the Fisheries Sector Economic Development Against Maritime North Maluku Province}

The multiplier effect in Table 6 employment in the year 2009 to 2013 the district/city in North Maluku province for capture fisheries sub-sector is not able to create job opportunities in the communities of North Maluku province. The multiplier effect, employment opportunities for capture fisheries subsector in 2010 regency/city of North Maluku province located in the district of West Halmahera of 2.3, 23.4 Central Halmahera district, North Halmahera of 4.1, at 11 East Halmahera, 5 and cities Tidore islands of which is 2.5. In this case, the employment opportunities in the fisheries sector occurred more labor in the district/city more labor most numerous in Central Halmahera district with the addition of the workforce by 23 people and in East Halmahera regency as many as 11 people. 
Table 6. Employment Multiplier Base North Maluku province Year 2009-2013

\begin{tabular}{lccccc}
\hline \multicolumn{1}{c}{ Regency/City } & \multicolumn{5}{c}{$\begin{array}{c}\text { Multiplier Base } \\
\text { (Multiplier effect) }\end{array}$} \\
\cline { 2 - 6 } & $\mathbf{2 0 0 9}$ & $\mathbf{2 0 1 0}$ & $\mathbf{2 0 1 1}$ & $\mathbf{2 0 1 2}$ & $\mathbf{2 0 1 3}$ \\
\hline West Halmahera & 0,0 & 2,3 & 0,0 & $-53,8$ & 180,2 \\
\hline Central Halmahera & 0,0 & 23,4 & 0,0 & $-3,9$ & 19,1 \\
\hline Sula Islands & 0,0 & $-0,2$ & 0,0 & $-1,4$ & 4,5 \\
\hline South Halmahera & 0,0 & $-4,2$ & 0,0 & 0,1 & 34,0 \\
\hline North Halmahera & 0,0 & 4,1 & 0,0 & $-23,4$ & $-3,6$ \\
\hline East Halmahera & 0,0 & 11,5 & 0,0 & 0,2 & 3,0 \\
\hline Morotai Island & 0,0 & 0,5 & 0,0 & 0,4 & $-5,2$ \\
\hline Ternate & 0,0 & $-4,2$ & 0,0 & 0,1 & 34,0 \\
\hline Tidore & 0,0 & 2,5 & 0,0 & 17,0 & $-3,9$ \\
\hline
\end{tabular}

Source: Data Processed, 2016

In 2011 to 2012 decline multiplier effect is significant and only in Tidore islands there is an increase or a more labor in fisheries sector with a number of 17.0 means more labor in capture fisheries subsector in Tidore city Islands for 15 people as in Table 6.

According, the official News Agency of Fisheries and Maritime province of North Maluku (2014), resource potential (standing stock) of fisheries in the waters of North Maluku is 1.03523 million tons per year and the value of fisheries production through 2013 as many as 151541 tons, North Maluku is a contributor to national fish production in 2013 World sequence 16. Sobari \& Farida (2007) mention that the fisheries and marine sector as a base sector should remain a priority in the development of the region. The need for vigorous efforts to encourage the private sector or the inverter to be willing to invest in the fisheries and marine sector. From the results of study Keristina (2001); Yuanda et al. (2012), mentions, sub-sector of fisheries as an base activity, the need for more efforts be improved to encourage the private sector to be willing to help invest in particular subsector of fisheries and undertake to improve facilities and infrastructure associated with capture fisheries such as services transport and communications-services that support capture fisheries.

\section{Results Analytical Hierarchy Process (AHP) Maritime Policy Strategy of Economic Development of North Maluku Province}

Priorities with respect to:

Combined

Goal: Economic Development Maritime

$\begin{array}{ll}\text { Natural resources } & 0,484 \\ \text { Human Resources } & 0,128 \\ \text { Economy } & 0,159 \\ \text { Public service } & 0,230 \\ \text { Inconsistency = 0,06 } & \\ \text { With 0 Missing Judgments } & \end{array}$

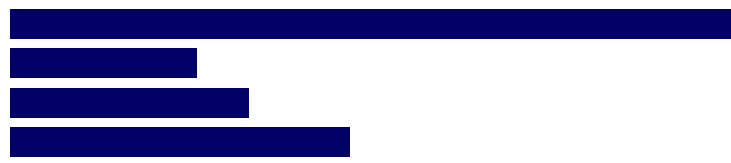

Figure 1. Comparison of Priority Weights All Criteria Source: Data Processed, 2016 
Maritime economic development strategy based on the results of the analysis showed the priority weighting matrix pairs can be seen that all the criteria of human resources (HR) is the most important criterion in the development strategy of the maritime economy of North Maluku, with priority weight of 0484 . The second priority is public service, with priority weight of 0.230 . The third priority is a natural resource, the priority weight of 0159 . And the fourth priority is the economy, with priority weighting of 0.128 . Results of analysis criteria maritime policy strategy of economic development of North Maluku as a whole in Figure 2, as follows:

Overall Inconsistency $=, 17$

Education \& Training
Society participation
Licensing
Infrastructure
transportation
Marine \& Fisheries
Quality Apparatus
capital Investments
Production Facility
Agriculture

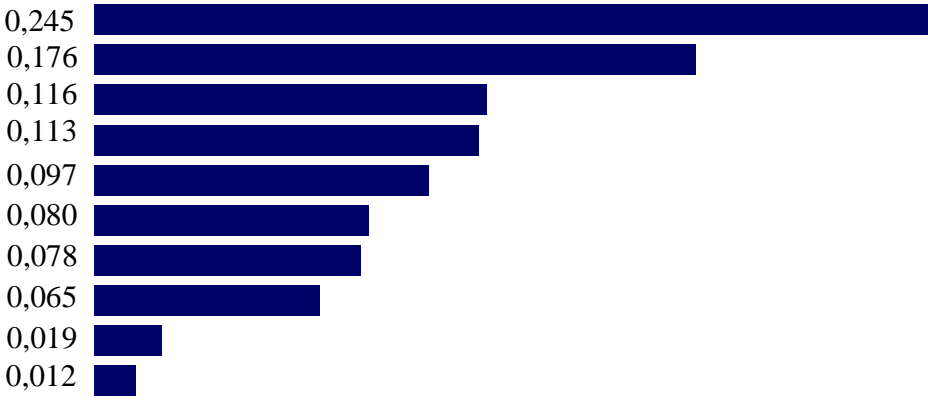

Figure 2. Criteria for Economic Development Aspects Maritime Source: Data Processed, 2016

Education and training to be priority with main criteria on human resources, it is associated with the skill and skills that need to be a major concern that is expected to provide the increased production increase public revenues, public participation has a value weighting of 0.352 become the second human resource priorities. Community involvement in the development of the maritime economy is essential. According to Kamaluddin \& Laode (2002), one of the important factors move the economic wheel that comes from the sea for a country is the availability of reliable human resources and professionals in the maritime sector.

The perception criteria of respondents licensing of public service is very important in figure 2 with the weight value of 0.461 , this is one of the main factors for the development of public service maritime economy in this case the business world in the district/city. On the infrastructure criteria a value of 0.330 . By developing the infrastructure district/city will be able to create growth centers so as to provide excellent service to the community. Provision of infrastructure such as roads, electricity, ports, docks port have the meaning to join the new strategy Palu-island separate by river or sea.

Priority of transportation, the weight value of 0.210 , the weight is raised by the respondent on the ground that, basic facilities and infrastructure has a role as an economic development stimulation in a region that is the show on the famine of transport that can transport people, goods, and services from one island to island another. The success of the maritime economic development must be supported by the facility (infrastructure) sea transport.

Criteria for fisheries and marine emphasized more fully in the economic development of North Maluku maritime, fisheries and marine and weighs 0.873. The number of islands in North Maluku as many as 805 pieces of the island and 
only $10 \%$ had been inhabited. North Maluku geographical conditions surrounded by the sea make this area rich in marine products. Capital investment by weighting the priority for 0772 . The second criterion is the priority of production facilities with priority weight of 0.228 . Of the two criteria, investment capital is considered highly priority of all respondents in because of the very important role of investment in the development of the maritime economy, in North Maluku province RPJMD Year 2014-2019. Explaining the underdeveloped regions in North Maluku province consisting of ten districts and the City, there are seven districts that are categorized as disadvantaged areas of which there are West Halmahera, North Halmahera, East Halmahera, Morotai Islands District, and the islands of Sula.

\section{CONCLUSION}

Sector and sub-sector featured among the regions for the economic development of the maritime province of North Maluku. The agricultural sector, the manufacturing sector, and the sector trade, hotels \& restaurants is a base sector between regions, while the fisheries subsector and sea transport sub-sector is a subsector that featured among the regions of North Maluku Province. South Halmahera regency and district, the islands of Sula a district that has featured most sectors and subsectors base in the district/city of North Maluku province. In the subsector of fisheries, in 2010 the subsector's fisheries provide employment opportunities simply means there is at the district West Halmahera, Southeast Halmahera, East Halmahera, North Halmahera and cities of Tidore Islands, in 2013 chance of working on a subsector of fisheries West Halmahera district, South Halmahera has multiplier effect on employment opportunities in the communities in the districts/cities. From the analysis of AHP, maritime policy strategy of economic development of North Maluku Province. In human resources is a top priority, aspects, priorities both aspects of public services, the third top priority, natural resources and economic aspects. Meanwhile, in the weighting of criteria with the highest weight value criteria contained in the marine and fisheries, education and training have criteria and licensing criteria.

There are three recommendations: first, a local government district/city of the province of North Maluku is to promote the development of the maritime economy by developing sectors and subsectors which is the base sector or sectors and subsectors non-base in districts/municipalities in order to create jobs for the community and generating local revenue. Second, increase employment opportunities in the fishery subsector, so the local government district/city of the province of North Maluku, serving in infrastructure, the addition of the fishing fleet, improving human resources, and encouraging investors to undertake investments to manage the subsector of fisheries and marine, and thirdly, implementing development the maritime economy, it is important the role of the government related to the development of human resources, namely local government district/city and province needs to improve the skills of cooperation. Provision of infrastructure to manage the natural resources and marine fisheries.

\section{REFERENCES}

Adisasmita. R. (2013). Economic Development Maritim. Yogyakarta: Graha Science. 
Aminuddin. (2015). Optimizing Utilization Maritime North Maluku. Retrieved http://ambon.antaranews.com/berita/27038/mengoptimalkan-pemanfaatanpotensi-maritim-maluku-utara.

Arikunto S. (2000). Management Research, New Edition. Jakarta: Rineka Cipta.

Arsyad, L. (1999). Pengantar Perencanaan dan Pembangunan Ekonomi Daerah, Edisi Pertama. Yogyakarta: BPFE.

Bernacki, D. (2014). Labour Market Developments In The Maritime Industry Of The South Baltic Region. Comparative Economic Research, 17(1), 129143.

BPS North Maluku province. (2014). Gross Domestic Product According to the field of Business North Maluku province. Ternate.

BPS North Maluku province. (2014). Gross Regional Domestic Product of North Maluku province 2009-2013. Provinsi North Maluku, Ternate.

Budianto, F, P., Susilo, E., \& Indrayani, E. (2013). Implementation of Development of Tourism in Small Island Coastal Community Lihunu Village, District Likupang, North Minahasa Regency, North Sulawesi. Economic and Social Fisheries and Maritime Journal, 1(1), 1-10.

Central Bureau of Statistics. (2015) North Maluku Ternate in Figures 2015.

Dahuri., \& Nugroho. (2012). Regional Development Perspectives on Economic, Social, and Environment. Jakarta. LP3ES.

Deputy maritime and Natural Resources. (2015). The Independent Economic Management and Sustainable maritime. Ministry of national development planning/national development planning agency. Retrieved from http://personal.its.ac.id/files/pub/4023-sautgparadigm\%20and\%20Orientasi \% 20Kebijakan\% 20Maritim\% 20Indonesia_2011.pdf.

Gusman, I. (2015). Orasi 'Poros' Maritim Irman Gusman di Kampus IPB. Retrieved from http://dpdri.merdeka.com/berita/orasi-poros-maritimirman-gusman-di-kampus-ipb-150902g.html.

Jiang, X.U., \& Liu, T.Y. (2014). China's Marine Economy and Regional Development. Marine Policy, 50, 227-237.

Kamaluddin, M., \& Laode, M. (2002). Economic Development in Indonesia. Jakarta. Gramedia.

Kaczynski, V. M., \& Looney, S. W. (2000). Coastal Resources as an Engine of Economic Growth and Reduction of Poverty in West Africa: Policy Considerations. Coastal Management, 28(3), 235-248.

Kerestina. (2011). Role and Impact of Capture Fisheries Sub-Regional Economic Cirebon. Major technology and management of fisheries Department of Fisheries Resource Utilization Faculty of Fisheries and Marine Science, Bogor Agricultural University. Bogor.

Manik, T., \& Sari, I. E. (2014). Analisis Pengaruh Industri Maritim Melalui Transportasi Perhubungan Laut, Pariwisata Bahari, Perikanan Tangkap terhadap Pendapatan Asli Daerah dan Pertumbuhan Aset. Jurnal Ekonomi Maritim Indonesia, 5(2), 1-15.

Marine and Fisheries Agency of North Maluku province. (2014). Book One Department of Fisheries and Marine Resources. North Maluku province.

Palgrave. (2006). Maritime Economics and Logistics' MEL Theme of Special Issue: Maritime Logistics and Global Supply Chains. Maritime Economics and Logistics, 8(1), 3-18. 
Riyadi, M., \& Smith. (2005). Coastal Resource Development Policy as an Alternative Future Development of Indonesia. Retrieved from http://www.bappenas. go.id/

Sjafrizal. (2008). Ekonomi Regional: Teori dan Aplikasi. Padang: Baduose Media.

Sobari, M.P., \& Farida, N. A. (2007). Role of Fishery and Oceanic Sector to Regional Development of Regency Kendal, Province Jawa Tengah. Buletin Ekonomi Perikanan, 7(1), 1-19.

Sudarya, D., Sitorus, S.R.P., \& Firdaus, M. (2013). Analisis Perkembangan Ekonomi Wilayah untuk Arahan Pembangunan Kecamatan di Wilayah Pesisir Kabupaten Garut. Jurnal Imiah Geomatika, 19(2), 134-140.

Yuanda, M. A., Dhahiyat, Y., \& Herawati, T. (2012). Struktur Komunitas Ikan di Hulu Sungai Cimanuk Kabupaten Garut. Jurnal Perikanan dan Kelautan, 3(3), 229-236. 